\title{
UMA ANÁLISE CONSTITUCIONAL DO ESTATUTO DE ROMA SEGUNDO CRITÉRIOS DE LEGALIDADE PENAL
}

\section{A CONSTITUTIONAL ANALYSIS OF THE ROME STATUTE ACCORDING TO CRITERIA OF PENAL LEGALITY}

${ }^{1}$ Elisio Augusto de Souza Machado Júnior

\begin{abstract}
Resumo
O estudo tem como pano de fundo a influência exercida pelo processo de globalização ao constitucionalismo que se constrói a partir da segunda metade do século XX, com o final da Segunda Grande Guerra, tendo como marco a internacionalização das relações entre os Estados. Nesse contexto, estabelece como objeto de análise o Estatuto de Roma, símbolo de um novo direito penal internacional ainda não consolidado, tomando como hipótese que a relativização ao princípio da legalidade penal constitui obstáculo não só à aplicação direta das disposições do Estatuto, mas também à efetiva sujeição do Brasil à jurisdição do Tribunal Penal Internacional.
\end{abstract}

Palavras-chave: Constitucionalismo globalizado; Legalidade; Taxatividade; Estatuto de Roma; Tribunal Penal Internacional.

\begin{abstract}
The examination have as backdrop the influence exerted for the process of globalization to the constitutionalism that if constructs from the second half of twentieth century, with the end of the Second Great War, having as landmark the internationalization of the relations between the States. In this context, it establishes as analysis object the Rome Statute, symbol of a new international criminal law not yet consolidated, taking as hypothesis that the relativization the beginning of the penal legality not only constitutes obstacle to the direct application of the disposals of the Statute, but also to the effective subjection of Brazil to the jurisdiction of International Criminal Court.
\end{abstract}

Keywords: Globalized constitutionalism; Legality; Taxactivity ; Rome Statute International Criminal Court.

\footnotetext{
1 Mestrando em Direito pela Universidade Federal de Sergipe, UFS - SE, (Brasil). E-mail: elisio_machado@hotmail.com
} 


\section{INTRODUÇÃO}

Um novo modo de comportamento criminoso que opere efeitos em uma perspectiva internacional exige, também, abordagens inovadoras para que se possa dar uma resposta satisfatória às demandas sociais que impulsionam essa nova ordem global. Entretanto, é necessário compreender e aceitar os limites do direito penal, cuja utilização deve ser preservada enquanto instrumento último, quando alternativas outras não mais restarem.

$\mathrm{O}$ estudo da resposta jurídico-penal adequada à delinquência gerada pelos fenômenos da globalização e da integração supranacional tem suscitado calorosas discussões. A formatação desse novo direito penal internacional se mostra desde logo conscientemente flexível, segundo as regras clássicas de imputação, acentuando uma tendência expansionista pautada na relativização de garantias político-criminais, substantivas e processuais.

Em verdade, o desrespeito ao princípio da legalidade com referência às obrigações internacionais tornou-se um lugar comum, criando uma zona de conflito com as disposições internas que conformam princípios basilares à clássica noção de Estado Democrático de Direito. Entretanto, em que pese essa aparente inconstitucionalidade das disposições que hoje constituem a chamada parte geral desse direito penal internacional, que se descortina no horizonte como um caminho aparentemente sem volta, pouco se tem discutido acerca da sujeição à jurisdição do Tribunal Penal Internacional quando evidenciado o total descompasso aos direitos e garantias fundamentais assegurados no texto constitucional.

Com efeito, o tema proposto não só suscita questões de dogmática penal, mas também coloca em xeque a legitimidade dessa jurisdição supranacional apresentada pelo Estatuto de Roma, mormente quando em conflito com a sistemática adotada pela jurisdição penal interna. Inobstante abalizada doutrina sustente a aplicabilidade irrestrita das disposições do Tribunal Penal Internacional, com fundamento em critérios extraídos do Direito Internacional Público, a ausência de conformidade ainda existente com a realidade do nosso ordenamento jurídico-penal constitui obstáculo aparentemente intransponível.

Esses obstáculos dogmáticos não têm merecido a necessária atenção da comunidade internacional, que tem preterido a observância a princípios fundantes do direito penal na busca por fontes de legitimidade em critérios metajurídicos, a exemplo do direito consuetudinário, cuja vagueza pouco garante a vigência de direitos fundamentais subjetivos. Disso se extrai a importância do tema: o Estatuto de Roma, acaso fosse ele de fato aplicado no nosso ordenamento jurídico, criaria um embaraço à vigência e aplicabilidade de princípios dos 
quais não se podem abrir mão - não ao menos sem que se admita um retrocesso na proteção de direitos fundamentais.

Com efeito, a pesquisa partiu de uma análise acerca do princípio da legalidade, buscando substrato na compreensão do tema a partir de um ponto de vista constitucional. Para tanto, a estudo empreendido se estabeleceu através de um recorte dogmático, focado na taxatividade que caracteriza o direito penal, com o escopo de demonstrar a dissonância entre o fluido perfil de legalidade do Direito Internacional Público e as implicações que isto vem a provocar, considerada a sujeição do Brasil à jurisdição do Tribunal Penal Internacional.

$\mathrm{Na}$ tentativa de delimitar o objeto, se estabeleceu como marco teórico o novo direito constitucional que surge a partir da segunda metade do século XX, fortemente influenciado pelo fenômeno da globalização e pela internacionalização das relações entre Estados. Como método, optou-se pela revisão bibliográfica dos principais autores nacionais e internacionais que, direta ou indiretamente, tratam acerca do tema ou das questões por ele incidentalmente suscitadas.

\section{O NOVO CONSTITUCIONALISMO DO SÉCULO XX E SUAS IMPLICAÇÕES}

O positivismo filosófico foi fruto de uma idealização do conhecimento, na utópica pretensão de plenitude racional do saber; nada, que não a ciência, teria uma validade universal. Nas primeiras décadas do século $\mathrm{XX}$ o positivismo se tornou também a filosofia dos juristas. A partir de então, as construções doutrinárias empenharam-se na formatação de conceitos dogmáticos rígidos, na tentativa utópica de construir um ordenamento jurídico hermético, autossuficiente e prescindível de justificações externas.

Contudo, aquele positivismo jurídico, que se apresentava como ciência alheia a juízos valorativos, neutro e rigorosamente racional, findou assumindo uma função eminentemente política e ideológica, de início não apreendida. O formalismo acrítico, que equiparava o Direito à norma, limitava o debate acerca da justiça ao nível da positivação, legitimando assim a ordem estabelecida, qualquer que fosse ela (BARROSO, 2015, p. 275).

A derrocada do positivismo teve como combustível a queda dos regimes totalitários, sobretudo do nazismo na Alemanha, que com maior destaque utilizou o direito para consolidar seu aparato organizado de poder. Em percuciente análise, Hannah Arendt explica que, "nos primeiros anos de poder, os nazistas desencadearam uma avalanche de leis e decretos, mas nunca se deram ao trabalho de abolir oficialmente a Constituição de Weimar" 
(ARENDT, 1989, p. 444). Não havia o reconhecimento de força normativa à Constituição, completamente esvaziada em importância dentro do ordenamento jurídico. Tratava-se da manifesta utilização da norma como reforço ao postulado de que a lei e a ética do Estado Total seriam equivalentes.

Após um período envolto por trevas ditatoriais, eis que surge um novo alvorecer. Com os influxos democráticos na Europa, ato contínuo à Segunda Guerra Mundial, redefiniuse o lugar da Constituição como centro de gravidade do ordenamento jurídico; um núcleo intangível, elementar à construção do Estado Democrático de Direito. Nesse contexto, o póspositivismo - nomenclatura provisoriamente atribuída para simbolizar a superação da antiga formatação positivista - se edifica como o farol a guiar o mundo ocidental nesse processo de reestruturação.

Embora parcialmente deferente ao direito positivado, essa nova concepção desafiou a separação entre direito, moral e política, no que se costumou chamar de "virada kantiana". Essa retomada do diálogo com a ética, a partir de um ideal de justiça que antes simbolizava o a concepção jusnaturalista, autoriza colocar esse novo constitucionalismo como uma espécie de terceira via: ao passo que não desconhece a importância da segurança jurídica de um direito com disposições claras e objetivas, reintroduz os valores na interpretação jurídica, atribuindo normatividade aos princípios (BARROSO, 2015, p. 520).

Esse "constitucionalismo contemporâneo" que surge no decorrer do século XX, "centrado na ideia de constituição programática, sedimentando forte conteúdo social" (SOARES; RIGOLDI, 2013, p. 433), está diretamente associado ao "constitucionalismo globalizado", ao qual André Ramos Tavares identifica como a busca de ampliação dos ideais e princípios jurídicos adotados pelo mundo ocidental, na tentativa de universalização dos mesmos (TAVARES, 2012, p. 38). Por sua vez, a ele se aproximam as premissas do que o jurista argentino José Roberto Dromi (1997) denominou como el constitucionalismo del porvenir, em alusão ao futuro das Constituições (RIGOLDI, 2013). Dentre elas destacam-se precisamente os valores de integração e universalização, através dos quais se evidencia um caminho de transnacionalidade.

Torna-se clara a correlação entre o novo constitucionalismo e a globalização, cujos novos paradigmas não podem ser alijados ou desconsiderados nesse processo evolutivo. A capilaridade desse fenômeno engloba a diversos conceitos que lhe ensejam uma visão multifacetada, destacadamente o surgimento de um novo modelo econômico, a introdução da 
tecnologia nos mais diversos setores da vida social, e uma nova ordem política decorrente da aproximação entre Estados. É evidente que o Direito, enquanto produto histórico-cultural, não poderia passar ao largo dessa internacionalização.

Nesse contexto, antigos dogmas de soberania estatal foram fortemente relativizados, cedendo espaço a organismos supranacionais que não se submetem à clássica noção de territorialidade como critério que delimita o alcance da vigência normativa. Conforme sintetizado por Alicia González Vidaurri (2010, p. 1.215), “a globalização econômica e tecnológica está desintegrando os conceitos de soberania, de territorialidade da lei e dos Estados nacionais que formalmente se ostentavam como modernos, eliminando as fronteiras" (tradução livre) $)^{2}$.

É preciso reconhecer que "a Constituição não está desvinculada da realidade histórica concreta do seu tempo" (HESSE, 2009, p. 138); ao contrário, deve responder aos influxos sociais que condicionam a própria efetividade das suas disposições. Essa íntima relação entre normatividade e a vinculação do direito com a realidade foi apreendida por essa nova leva de textos constitucionais editados após o marco da Segunda Grande Guerra, fortemente marcados pela proteção e realização dos direitos fundamentais no contexto de uma nova ordem mundial.

Para Ingo Wolfgang Sarlet (2015, p. 54), a evolução desses direitos fundamentais revela que a implementação em nível global depende, cada vez mais, de esforços integrados. Mesmo a efetiva concretização em âmbito interno, depende, em última análise, de um esforço coletivo, consagrando a inevitável tendência ao reconhecimento de que a proteção dos direitos fundamentais - que cada vez mais se aproximam dos direitos humanos - deve ocorrer não só internamente, mas também segundo uma nova universalidade.

Há uma inequívoca influência dessa perspectiva contemporânea no campo do Direito Penal, impelido que fora a responder à delinquência gerada pelos fenômenos da globalização e da integração supranacional. Essa consequente adequação ocorreu não somente através da inserção de novos tipos penais na legislação nacional, mas, sobretudo, na criação de mecanismos de cooperação internacional, pondo em xeque princípios basilares de competência jurisdicional dos Estados e a própria base conceitual da teoria do delito, que classicamente se assenta em garantias formais e materiais (SÁNCHEZ, 2010, p. 1.284).

\footnotetext{
2 "la globalización economica y tecnológica está desintegrando los conceptos de soberanía, de territorialidad de la ley de los Estados nacionales que formalmente se ostentaban como modernos, eliminando las fronteras".
} 
O exemplo mais emblemático está consagrado no $\S 4^{\circ}$ do art. $5^{\circ}$ da Constituição Federal, que reconhece a submissão do Brasil à jurisdição de Tribunal Penal Internacional a cuja criação tenha manifestado adesão ${ }^{3}$. Entretanto, conforme será visto, o Estatuto de Roma do Tribunal Penal Internacional está assentado em uma lógica que, inobstante aceita no campo do Direito Internacional Público, flexibiliza severamente a taxatividade penal, cuja discussão está inserida na força vinculante do princípio da legalidade, parte indissociável do núcleo duro dos direitos fundamentais de primeira dimensão.

\section{O CONCEITO DE PRINCÍPIO E SUA INFLUENCIA NO PROCESSO DE CONSTITUCIONALIZAÇÃO DO DIREITO PENAL}

A Constituição Federal de 1988, sobretudo no catálogo de garantias e direitos fundamentais do artigo $5^{\circ}$, possui impacto direto sobre a validade e interpretação das normas de direito penal, que tem no texto constitucional sua fonte normativa primária. Dessarte, conhecer o caráter vinculante, também associado à força normativa da Constituição, dos princípios nela plasmados, expressa ou tacitamente, e o efeito que os mesmos exercem na compreensão do ordenamento jurídico e na aplicabilidade, fruto de um processo interpretativo das disposições infraconstitucionais, é crucial ao fenômeno da constitucionalização do direito.

Na visão de Luís Roberto Barroso (2015, p. 522), “a constitucionalização identifica um efeito expansivo das normas constitucionais", que se protraem pelo ordenamento jurídico como lentes hermenêuticas utilizadas como instrumento para correta compreensão das normas. Os valores morais compartilhados por toda a comunidade, em dado momento e lugar, contemplados nos princípios da Constituição Federal passam a condicionar a validade e o sentido das disposições infraconstitucionais, sujeitas que estão ao filtro contínuo da interpretação constitucional.

Robert Alexy (2015, p. 575), em posfácio à sua obra "Teoria dos Direitos Fundamentais", afirma que a tese central do seu livro é a de que os direitos fundamentais, independentemente de sua formulação mais ou menos precisa, têm a natureza de princípios e são "mandamentos de otimização". Significa dizer que "princípios são normas que ordenam que algo seja realizado na maior medida do possível dentro das possibilidades jurídicas e fáticas existentes" (ALEXY, 2015, p. 90).

\footnotetext{
${ }^{3}$ O referido parágrafo, acrescido pela Emenda Constitucional $n^{\circ} 45$ de 2004, alude ao Estatuto de Roma do Tribunal Penal Internacional, promulgado pelo Decreto $\mathrm{n}^{\circ} 4.388$, de 25 de setembro de 2002.
} 
Ao contrário das regras, que obedecem a uma lógica binária de tudo ou nada, satisfeitas ou não satisfeitas, os princípios admitem uma gradação. Ou seja, mesmo em caso de colisão aparente, o princípio cedente, em determinada conjuntura fática, permanecerá plenamente válido. Trata-se de um critério de ponderação momentânea; "nada impede que, em caso diverso, com outras características, o princípio antes preterido venha a prevalecer" (BRANCO; MENDES, 2012, p. 84).

A importância decorre do fato de que a simples cognição do direito legislado não oferece muita coisa, havendo uma consequente necessidade de interpretação jurídica dos fatos que ultrapassa a mera subsunção à norma. Na esteira de Konrad Hesse (2009), são os princípios que servem para concretização dessas normas, garantindo uma unidade ao ordenamento a partir de uma interpretação da legislação infraconstitucional em conformidade ao programa normativo. Nessa linha, os princípios desempenham uma função dúplice: argumentativa, dentro de um discurso jurídico para solução do caso concreto; e como baliza ao adequado exercício do Poder Legislativo, reconhecendo na Constituição tanto uma moldura que delimita a discricionariedade do legislador quanto o fundamento para definir objetivos.

\section{A IMPORTÂNCIA DO PRINCÍPIO DA LEGALIDADE PENAL}

Após um longo período de exceção marcado pela Ditadura Militar, a Constituição Federal de 1988, resultado da vitoriosa superação de um tempo onde a arbitrariedade era a regra, logo tratou de proteger os direitos e garantias fundamentais antes relativizados, criando um rol que hoje se compreende como não exaustivo. Lê-se no artigo $5^{\circ}$, inciso XXXIX, que “não haverá crime sem lei anterior que o defina, nem pena sem prévia cominação legal". Não se pode compreender esta norma de outro modo que não como um imperativo, a inadmitir desvios ou ressalvas.

Trata-se do princípio da legalidade, fundamental à compreensão do direito penal em um Estado Democrático de Direito, que invariavelmente deve controlar o poder punitivo estatal mediante a aplicação de limites tendentes a excluir excessos punitivos. Posto isso, o conceito é mais amplo que a simples incorporação no ordenamento jurídico de normas legais escritas, claras e precisas. Em última análise, sai ele da esfera estritamente formal do nullum crimen, nulla poena sine lege, propiciador da aplicação do direito de punir, para atingir, proteger e garantir os direitos fundamentais como um todo (GIACOMOLLI, 2010, p. 455). 
Destarte, um preceito penal apenas encontra seu fundamento de validade desde que respeitados os critérios extraídos desse princípio, o qual rechaça conceitos vagos e a necessidade de complementação valorativa para atribuir significado a uma regra coercitiva que, invariavelmente, deve ser precisa em suas disposições. Uma lei indeterminada ou imprecisa, e por isso pouco clara, não pode proteger ao cidadão da arbitrariedade, porque não implica em uma autolimitação do jus puniendi estatal a que se possa recorrer; ademais, é contrária ao princípio da divisão de poderes, ao passo que franqueia ao juiz a liberdade de fazer qualquer interpretação que queira, invadindo o terreno do legislativo através do ofício judicante.

Na visão de Claus Roxin (1997, p. 169), uma lei de tal modo abstrata não é capaz de implementar uma eficácia preventivo-geral, "porque o indivíduo não pode reconhecer aquilo que se quer proibir; e precisamente por isso sua existência tampouco pode proporcionar a base para uma reprovação da culpabilidade" (tradução livre) ${ }^{4}$. Dessarte, o princípio da legalidade ou taxatividade penal constitui uma espécie de armadura em defesa ao direito fundamental à liberdade, que apenas poderá ser mitigado em casos excepcionais, desde que se tenha validamente reconhecido determinado comportamento como um fato típico.

Tal princípio, enquanto direito fundamental subjetivo, não só garante a imparcialidade no tratamento, mas também confere ao cidadãoa inquebrantável tranquilidade de que, sob a égide de um Estado Democrático de Direito, não será ele sumariamente arrebatado e submetido a ferros por algo que, ao tempo em que praticado, não constituía um ilícito penal. Do ponto de vista político, significa afirmar que o desrespeito ao contrato social que legitimamente autoriza a coerção estatal pressupõe do cidadão o prévio conhecimento das regras sociais estabelecidas, que somente pode ocorrer mediante a formulação de preceitos claros, precisos e determinados.

No que concerne à criação de tipos penais, pode-se dizer que pelo princípio da legalidade o processo de elaboração de preceitos incriminadores é função exclusiva da lei, que deve ser taxativa ao definir a conduta proibida e equalizar os limites da pena aplicável. Por sua vez, ao legislador é proibido cominar pena a um comportamento indeterminado, vez que a legitimidade da sanção pressupõe uma estreita vinculação à descrição de um comportamento em abstrato.

\footnotetext{
4“"porque el individuo no puede reconocerlo que se le quiere prohibir; y precisamente por eso su existencia tampoco puede proporcionar la base para un reproche de culpabilidad".
} 
Tudo isso conduz à compreensão de que a determinação legal é essencial à sistematização do direito penal, que não pode ser evitada pela remissão a um direito costumeiro como sendo fonte legítima. Na visão de Günther Jakobs (2009, p. 136), que destaca a preocupante utilização dos costumes como critério vinculante para complementação de lacunas ou imposição de pena, antecipando em parte a crítica que será feita adiante, "no que concerne o princípio da legalidade, ele não pode nunca ser eludido por meio do Direito Consuetudinário, pois a violação dos princípios do Estado de Direito não se converte em Direito nem mesmo quando se dá conforme o uso ou optima fide".

\section{O TRIBUNAL PENAL INTERNACIONAL E O DESRESPEITO AO PRINCÍPIO DA TAXATIVIDADE}

Os fatores de internacionalização das relações forçaram o direito penal clássico a abandonar o conforto da territorialidade e buscar na contemporaneidade uma via para torná-lo aplicável também extramuros, manifestando interesse pelo julgamento de crimes cometidos fora do âmbito de soberania estatal. O objetivo fundamental desse direito penal internacional, fruto do fenômeno da globalização, é de ordem eminentemente prática: dar uma resposta minimamente uniforme ou, ao menos, internacionalmente harmonizada, à chamada delinquência transnacional, que sofreu inegável incremento após a Segunda Grande Guerra.

Após tentativas reiteradas de criar um nível mínimo de conformação interna entre as legislações penais, no sentido de viabilizar uma cooperação internacional, chegou-se ao amadurecimento da discussão quanto aos contornos de um direito penal supranacional. Nesse contexto, costuma-se reconhecer nos Tribunais Internacionais ad hoc versões que se sucederam no caminho para construção de uma jurisdição internacional em matéria penal. A criação de uma Corte Internacional permanente, entretanto, trouxe a tona o debate sobre a consolidação do fenômeno de universalização da justiça penal, que ainda não atingiu uma necessária harmonização de suas normas.

Tratar acerca da legalidade no âmbito do Estatuto de Roma do Tribunal Penal Internacional (TPI), tema fulcral deste artigo, implica de antemão não só aceitar as dificuldades de uniformização de sistemas diversos, mas também no reconhecimento dos problemas decorrentes de um conflito interno aparente, provocado pela submissão do Brasil à jurisdição do TPI, na medida em que este não se sujeita aos mesmos critérios que delimitam a imputação penal no nosso ordenamento jurídico. 
O jurista italiano Sergio Mocca, analisando a híbrida relação entre aspectos penais e políticos que marcam o Estatuto do TPI, conclui que "o direito penal internacional representa algo diverso do direito penal" (2010, p. 1.089). Na dinâmica internacional, é difícil se chegar a um ponto de equilíbrio entre os Estados e as múltiplas fontes que cada realidade jurídica interna representa, fato que contribui decisivamente, embora não justifique, o nível de imprecisão verificado. Essa busca por unidade que pudesse minimamente apaziguar as arestas provocadas pela tentativa de junção de diversos sistemas implicou na relativização de garantias, com o escopo de responder a exigências contingenciais das instâncias políticas dos diversos Estados, criando uma nova racionalidade penal assentada em um conceito volátil de legalidade.

Para a análise proposta no presente artigo, são particularmente importantes os artigos 22 a 25 do Estatuto do TPI. Estes, ao dispor sobre os princípios gerais de direito penal, constituem a base fundante do que se entende por legalidade no âmbito penal internacional. Além deles, é essencial abordar os artigos $9^{\circ}$ e 21 , que tratam, respectivamente, dos elementos constitutivos do crime e das fontes do direito aplicável. Já quanto ao princípio da legalidade das penas, destaca-se o artigo 77, que não estabelece parâmetros ou gradações para sanção aplicável, admitindo inclusive a pena de prisão perpétua.

A heterogeneidade das fontes criadoras do Estatuto do TPI, aliada à forte carga política e ideológica dos crimes submetidos à sua jurisdição, dificultam uma observância aos componentes da legalidade, como também amplia de maneira excessiva o campo de discricionariedade na interpretação de suas disposições - não só quanto aos tipos penais, ademais sujeitos a alterações nos termos do artigo $9^{\circ}$ do Estatuto de Roma, mas também às penas, que não se sujeitam a critérios de razoabilidade em sua cominação.

Quanto aos crimes submetidos à jurisdição do $\mathrm{TPI}^{5}$, selecionados pelo suposto nível de gravidade e alcance internacional, a amplitude e a extensão da ação típica que lhe são inerentes acabam levando a subsunção de muitos dos casos a tipos penais comuns, a exemplo dos crimes contra a vida, contra a integridade física e contra a dignidade sexual, cuja regulação interna não se equivale aos fins pretendidos pela Corte Internacional Permanente. Com efeito, o baixo nível de exatidão e a amplitude terminológica na definição dos crimes internacionais - que nada mais são que crimes comuns praticados, via de regra, em maior

\footnotetext{
${ }^{5} \mathrm{O}$ artigo $5^{\circ}$ do Estatuto de Roma determina quais são os crimes compreendidos dentro da jurisdição da Corte, quais sejam: "a) crime de genocídio; b) crimes contra a humanidade; c) crimes de guerra; d) crime de agressão".
} 
escala ou em determinado contexto - contribuem em larga escala para inefetividade das disposições do Estatuto de Roma, sobretudo quanto aos crimes de genocídio e de agressão.

Entretanto, há na doutrina quem atribua responsabilidade não às deficiências do Estatuto do TPI, mas à realidade dos Estados, que teriam a obrigação de adequar seus ordenamentos para garantir a eficácia da jurisdição internacional. Nesse sentido, sustenta Albin Eser (2013, p. 161) quanto à "necessidade de transcendência do direito nacional”, no sentido de que todos os países deveriam estar obrigados, pelo Direito Internacional Público, a sancionar penalmente dentro dos seus respectivos ordenamentos tudo aquilo que estiver proibido pelo direito internacional.

Para o autor, em leitura ao princípio da complementariedade ${ }^{6}$ previsto no artigo $1^{\circ}$ do Estatuto de Roma, os países que ainda não fizeram tal ajuste deveriam ver-se obrigados a fazê-lo. Contudo, esse hipotético ajuste não poderia jamais conferir validade interna às disposições do TPI, em detrimento da integridade do próprio ordenamento jurídico nacional.

Posição semelhante é sustentada por Paul Hernández Balmaceda, com base na hierarquia das normas de Direito Penal Internacional, segundo ele superior à regulação do direito interno. Segundo o autor, é necessária adequação dos ordenamentos internos em todos os níveis ao exigido na norma internacional:

deste princípio de cooperação, concebido na forma com que o estamos referindo, surge então para o Estado uma dupla obrigação: a da prevenção, que se concretiza na emissão de normas que punam ou adaptem ao direito interno as condutas contidas nas normas convencionais; e a obrigação de repressão, que se concretiza na persecução de tais ilícitos quando são submetidos perante seus tribunais (BALMACEDA, 2010, p. 1.053).

Seria esta uma possível saída para obstar que o Tribunal Penal Internacional, utilizando como argumento a incapacidade de um país para realizar a persecução penal, avocasse um processo relativo a fato amoldado como ilícito internacional, em detrimento da jurisdição penal interna. A crítica de fato é pertinente, sobretudo à realidade de omissão legislativa do Brasil que, ao contrário de outros países latino-americanos, não editou uma Lei de aprovação do TPI ou incorporou os tipos penais concebidos como crimes internacionais, fato que poderia dar uma solução, ao menos intermediária, no sentido de compatibilizar as diversas antinomias existentes.

\footnotetext{
${ }^{6}$ Segundo o princípio da complementariedade, o Tribunal Penal Internacional tem jurisdição sobre as pessoas responsáveis pelos crimes de maior gravidade com alcance internacional, sendo um órgão complementário às jurisdições penais nacionais, e não um substituto às mesmas.
} 
Por outro lado, a inexistência de uma normativa interna de remissão reforça a inaplicabilidade imediata dos tipos penais do Estatuto de Roma, que sequer possui na realidade do ordenamento jurídico interno uma superioridade hierárquica à legislação infraconstitucional ${ }^{7}$. Ao observar as provisões dos artigos $5^{\circ}$ a $8^{\circ}, 77$ a 80 do Estatuto, para nenhuma das condutas parcamente descritas se atribuíram limites específicos de pena, de modo que não se pode quanto a eles sustentar uma observância às exigências dogmáticas que delimitam a potestade (BALMACEDA, 2010, p. 1.057). Tem-se aí um nó górdio: embora tenha sido expressamente reconhecida a jurisdição da Corte Penal Internacional, nada se fez para viabilizar que fosse ela exercida sem o sacrifício de direitos e garantias fundamentais historicamente conquistados a duras penas.

Diante desse descompasso, não se pode aceitar por presunção que as deliberações do TPI, enquanto órgão plurinacional, reflita o pensamento da maioria dos Estados, como de maneira ingênua propõe Adauto Suanes (2010, p. 643). Inobstante se possa reconhecer certo nível de representatividade do órgão deliberativo, isso não basta para que disposições penais contrárias a direitos e garantias fundamentais sejam acriticamente incorporadas ou admitidas no ordenamento jurídico como válidas e impositivas.

Quanto ao processo de criação das disposições penais propriamente ditas, vale ainda ressaltar que o princípio da legalidade em matéria penal também requer um processo legislativo. Disso decorre que o TPI, enquanto órgão de poder estruturado de modo burocrático, não pode criar leis penais diretamente, nem pode determinar aos parlamentos que aprovem leis penais com fundamento no princípio da complementariedade, como já destacado em linhas gerais por Bernd Schünemann (2013, p. 267) ao criticar o poder normativo da União Europeia.

Ressalvado o crime de genocídio, nacionalmente tipificado através da Lei $\mathrm{n}^{\circ}$ 2.889/1956, em termos equivalentes ao do artigo $6^{\circ}$ do Estatuto de Roma, o rigor interno garantido pelo princípio da legalidade penal difere das previsões nele contidas. Sem uma

\footnotetext{
${ }^{7}$ Nesse sentido, vale destacar que o Estatuto de Roma do Tribunal Penal Internacional não se amolda ao conceito de "tratado ou convenção internacional sobre direitos humanos", de modo que não possui status jurídico de norma constitucional, nos termos do artigo $5^{\circ}, \S 2^{\circ}$, da CF, nem equivalente às emendas constitucionais, nos termos do $\S 3^{\circ}$ do mesmo dispositivo constitucional. Com efeito, discordando da posição de Valério de Oliveira Mazzuoli (2010, p. 1.111), o Estatuto do TPI tanto não servirá de paradigma do controle de convencionalidade, como também não serve como parâmetro ao controle de supralegalidade das normas infraconstitucionais. Tal compreensão está assentada na posição adotada pelo STF, consolidada a partir do julgamento do RE $\mathrm{n}^{\circ}$ 80.004/SE, segundo a qual há tão somente uma paridade hierárquica entre os tratados internacionais regularmente ratificados pelo Brasil e a legislação infraconstitucional (SARLET; MARINONI; MITIDIERO, 2016, pp. 207/208).
} 
norma interna de remissão, que então pudesse adequar as incongruências entre sistemas penais construídos a partir de lógica diversa, não só a aplicabilidade direta dos tipos penais de competência do TPI se mostra juridicamente impossível, mas também se torna questionável a submissão do Brasil à sua jurisdição, relativizando assim a eficácia da disposição contida no $\S$ $4^{\circ}$ do artigo $5^{\circ}$ da Constituição Federal.

Ademais, uma interpretação sistemática do Estatuto autoriza afirmar que o supracitado princípio da complementariedade opera efeitos meramente formais; algo problemático diante do evidente descompasso com o ordenamento jurídico nacional. Há que se recordar, antes de tudo, que em matéria de Direito dos Tratados dispõe o artigo 26, da Convenção de Viena, o caráter vinculante dos mesmos. Em síntese, para o Direito Internacional Público, um Estado que legitimamente pactua em determinado sentido se encontra obrigado a cumprir o compromisso assumido frente à comunidade internacional.

Com base nisso, o direito consuetudinário - reconhecido como fonte legítima para o Direito Internacional Público - criou uma espécie de obrigação de cooperação universal, como padrão de comportamento que se espera dos Estados soberanos. Esse entendimento também encontra apoio no $\S 3^{\circ}$ do artigo $1^{\circ}$ da Carta da Organização das Nações Unidas, bem como em diversos instrumentos do Direito Internacional Humanitário, dos quais se depreende uma obrigação tácita de reprimir os crimes internacionais que hoje se sujeitam à competência do TPI (BALMACEDA, 2010, p. 1.052).

O Estatuto de Roma, em específico, conquanto afirme sua jurisdição como de caráter secundário, estabelece em seu artigo 12 uma sujeição dos Estados que se tornem parte à jurisdição do TPI, relativamente aos crimes de genocídio, crimes contra a humanidade, crimes de guerra e o crime de agressão, nos termos do seu artigo $5^{\circ}$. Além disso, criou-se uma hierarquia no que toca ao direito aplicável, cujo rol privilegia primeiramente as disposições constantes no próprio Estatuto, seguido pelos princípios e normas de direito internacional aplicáveis, incluindo os princípios estabelecidos no direito internacional dos conflitos armados. Apenas na falta destes é que se autoriza o Tribunal a retirar do direito interno dos diferentes sistemas jurídicos existentes princípios gerais aplicáveis, desde que não haja incompatibilidade com o próprio Estatuto, com o direito internacional, nem com as normas e padrões internacionalmente reconhecidos.

A sistemática estabelecida autoriza, dentre outras coisas, utilizar como fonte legítima princípios que se fundamentam no costume reiterado, extremamente difíceis de 
serem aceitos e identificados no plano interno, dado que se tratam de direito internacional não escrito. Isso implica em uma evidente desformalização, considerada a carga normativa da taxatividade penal. Nem mesmo a previsão dos crimes de competência do TPI é capaz de diminuir a crise suscitada pelas disposições do Estatuto de Roma ao princípio da legalidade, na medida em que diversos âmbitos de regulação foram propositalmente deixados em aberto por questões de política criminal, empoderando o julgador com a função atípica de ser ele também o legislador do caso concreto.

Como bem salientado por Kai Ambos, ao apresentar as bases de sua pesquisa para formatação de uma almejada parte geral do direito penal internacional,

\begin{abstract}
no que diz respeito, em particular, às fontes do direito penal internacional, a fundamentação no direito consuetudinário de normas de direito penal internacional coloca especiais dificuldades em um duplo sentido. Desde a ótica do direito penal, o princípio do nullum crimen parece excluir a existência de tipos penais não escritos, fundados no costume internacional (AMBOS, 2008, p. 44).
\end{abstract}

A proibição de retroatividade penal, por exemplo, que se fundamenta justamente na exata descrição da conduta vedada, não é entendida pelo Direito Internacional Público de modo estritamente formal, ou seja, como um princípio que exige um tipo penal escrito e anterior à comissão do fato. Segundo Kai Ambos (2008, p. 102), a proibição da retroatividade, no direito penal internacional, deve ser interpretada à luz de um ordenamento jurídico dinâmico, razão pela qual é internacionalmente suficiente que a ação seja punível segundo princípios não escritos de direito consuetudinário.

Embora essa inexigibilidade de determinação formal seja admitida no plano internacional, no sentido de um ordenamento jurídico escrito e suficientemente claro em suas disposições, tal nível de insegurança é impossível de ser aceito no ordenamento jurídico interno, assentado na proteção da confiança que subjaz ao direito fundamental à liberdade. De modo tal, se afigura temerário conceber que uma prática reiterada possa validamente criar um parâmetro de legalidade penal, que tem como principal característica a taxatividade, que confere segurança jurídica quanto às suas disposições.

A excessiva elasticidade de tal concepção vem expressamente admitida no $\S 1^{\circ}$ do artigo 12 do Estatuto de Roma, que, embora reconheça a irretroatividade, não sujeita a jurisdição do TPI ao princípio da reserva legal, admitindo assim que as imprecisões inerentes à volatilidade da norma fundada em práticas reiteradas sejam levadas a cabo (MOCCIA, 2010, p. 1.086). Tudo isso é resultado de uma exiguidade das normais penais contidas no 
Estatuto - da descrição do fato penal, antes de tudo, mas também das disposições da parte geral como um todo -, criando diversas lacunas normativas que torna necessário recorrer a instrumentos muito amplosde integração supletiva.

Admitir a existência desses vazios legais implica aceitar o risco de decisões arbitrárias em níveis cada vez maiores, deformando a função jurisdicional primária de interpretar e aplicar a lei para verdadeiramente criá-la, com base em critérios imprecisos que não oferecem o mínimo de segurança jurídica, a exemplo da norma costumeira não positivada. Considerado o baixo nível de taxatividade do Estatuto de Roma, que mais se preocupa com questões processuais e procedimentais, aliada à insuficiência de suas normas penais, a regra é que haja um uso dos princípios em níveis de arbítrio judicial inaceitáveis.

Por outro lado, essa taxatividade que se vê relativizada pelas disposições do Estatuto do TPI não importa apenas sob o aspecto da tutela da liberdade. Ela exerce uma explicação também quanto às finalidades da pena, que historicamente estão direcionadas, ao menos sob o ponto de vista teórico do dever-ser, à diminuição futura da prática de novos delitos e à recomposição do tecido social através da ressocialização do apenado.

Embora suscite discussões extremamente férteis, foge aos limites aqui propostos incursionar na falácia da finalidade da pena, desconstruída que fora pelos estudos levados a efeito pela criminologia crítica. A utilização desse lugar comum da teoria da pena, contudo, serve como reforço à compreensão de que o Estatuto do TPI trata acriticamente a sanção penal como um consectário automático de um juízo de culpabilidade; uma visão meramente retributiva e assentada em uma visão contratualista, sem lhe atribuir qualquer função legítima além de um vetusto "pagamento" pelo ilícito praticado. 


\section{CONCLUSÃO}

Demonstrou-se que a discussão que se estabelece acerca do princípio da legalidade penal, associada à noção de devido processo legal, não se limita às formulações classicamente apresentadas pela teoria da cominação penal, no sentido de conferir maior exatidão ao fato e à pena. A garantia de objetividade, além de afastar o indeterminismo, implica numa proibição de generalização de tipos penais e, consequentemente, contribui para a formação de um sistema que imponha limites ao processo interpretativo e ao alcance do texto legal. Trata-se, pois, de uma conquista libertária da qual não se pode abrir mão.

Ao contrário, a imprecisão criada por conceitos fluidos e pela adoção do direito consuetudinário como fonte legítima, tal como ocorre no Estatuto de Roma, constrói campo fértil ao uso simbólico do direito penal em nível internacional, permitindo uma maleabilidade que autoriza o direcionamento político da norma e da sanção aos opositores do poder institucionalizado. Dessarte, não se pode admitir a coexistência de um sistema paralelo, fundado em uma racionalidade penal deferente a razões políticas que, na tentativa de apaziguar ordenamentos jurídicos diversos, relativiza sobremaneira garantias elementares à proteção dos direitos fundamentais daqueles submetidos à jurisdição do TPI.

Por tudo quanto exposto, chega-se à conclusão de que as disposições contidas no Estatuto de Roma são incompatíveis com a ordem vigente. Ao menos até que seja editada uma Lei que estabeleça a necessária adequação ao ordenamento jurídico interno, uma total sujeição do Brasil à jurisdição do Tribunal Penal Internacional, dada a incontroversa desobediência ao princípio da taxatividade, se afigura temerária. Por outro lado, não se pode com isso afirmar de maneira conclusiva que uma jurisdição supranacional permanente implicará sempre em retrocessos quanto à efetivação de direitos e garantias fundamentais.

Os problemas descritos, relacionados à insatisfatória observância à legalidade penal, evidenciam as incongruências de um sistema ainda incipiente, construído a partir de finalidades políticas que não se amoldam aos núcleos intangíveis do direito penal. Com efeito, as críticas devem ser dirigidas não à instituição de uma Corte Penal Internacional permanente - que parece ser um avanço no que toca à persecução penal de crimes globais de extrema gravidade -, mas sim ao nível de insegurança decorrente das vagas disposições do Estatuto de Roma, que ainda carece de elementos que permitam maior adequação às conquistas democráticas que cada Estado tenha logrado atingir. 


\section{REFERÊNCIAS BIBLIOGRÁFICAS}

ALEXY, Robert. Teoria dos direitos fundamentais. Trad. Virgílio Afonso da Silva. 2. ed. São Paulo: Malheiros, 2015.

AMBOS, Kai. A parte geral do direito penal internacional: bases para uma elaboração dogmática. Trad. Carlos E. Adriano Japiassú, Daniel A. Raizman. São Paulo: Revista dos Tribunais, 2008.

ARENDT, Hanna. Origens do totalitarismo. Trad. Roberto Raposo. São Paulo: Companhia das Letras, 1989.

BALMACEDA, Paul Hernández. Aplicação direta dos tipos penais do Estatuto do Tribunal Penal Internacional no direito interno. In: FRANCO, Alberto Silva; NUCCI, Guilherme de Souza. Doutrinas essenciais - direito penal. São Paulo: Revista dos Tribunais, 2010, v. 1.

BARROSO, Luís Roberto. Curso de direito constitucional contemporâneo: os conceitos fundamentais e a construção do novo modelo. 5. ed. São Paulo: Saraiva, 2015.

DROMI, José Roberto. La Reforma Constitucional: El Constitucionalismo del "por-venir". In: ENTERRIA, Eduardo Garcia de; ARÉVALO, Manuel Clavero (coord). EI Derecho Público de Finales de Siglo: Una Perpectiva Iberoamericana. Madri: Fundación BBV, 1997, p.107-116.

ESER, Albin. Medidas nacionais e transnacionais contra a impunidade da criminalidade amparada pelo Estado e de crimes internacionais: conclusões de política jurídica a partir de um projeto comparado sobre a justiça de transição. In: AMBOS, Kai; Böhm, María Laura. Desenvolvimentos atuais das ciências criminais na Alemanha. Brasília: Gazeta Jurídica, 2013.

HESSE, Konrad. Temas fundamentais do direito constitucional. São Paulo: Saraiva, 2009.

JAKOBS, Günther. Tratado de direito penal: teoria do injusto e culpabilidade. Trad. Geraldo de Carvalho, Gercélia B.de Oliveira Mendes. Belo Horizonte: Del Rey, 2009.

MENDES, Gilmar Ferreira; BRANCO, Paulo Gustavo Gonet. Curso de direito constitucional. 7. ed. São Paulo: Saraiva, 2012.

MOCCIA, Sergio. O Tribunal Penal Internacional: os perfis de legalidade. In: FRANCO, Alberto Silva; NUCCI, Guilherme de Souza. Doutrinas essenciais - direito penal. São Paulo: Revista dos Tribunais, 2010, v. 1.

RIGOLDI, Vivianne; SOARES, Andréa Antico. O constitucionalismo do futuro de José Roberto Dromi: questões acerca da viabilidade de um constitucionalismo universal. Em tempo, Marília, v. 12, p. 428-446, 2013.

ROXIN, Claus. Derecho penal: parte general. Trad. Diego-Manuel Peña, Miguel Diaz Conlledo, Javier de Vicente Remansal. Madrid: Civitas, 1997, tomo I, p. 169. 
SÁNCHEZ, Jesús-María Silva. El derecho penal ante la globalizacion y la integracion supranacional. In: FRANCO, Alberto Silva; NUCCI, Guilherme de Souza. Doutrinas essenciais - direito penal. São Paulo: Revista dos Tribunais, 2010, v. 1.

SCHÜNEMANN, Bernd. As bases do processo penal transnacional. Trad. Heloisa Estellita. In: SCHÜNEMANN, Bernd; GRECO, Luís (coord). Estudos de direito penal, processual penal e filosofia do direito. São Paulo: Marcial Pons, 2013.

SARLET, Ingo Wolfgang; MARINONI, Luiz Guilherme; MITIDIERO, Daniel. Curso de direito constitucional. $5^{\text {a }}$ ed. São Paulo: Revista dos Tribunais, 2016.

A eficácia dos direitos fundamentais: uma teoria geral dos direitos fundamentais na perspectiva constitucional. 12. ed. Porto Alegre: Livraria do Advogado, 2015.

SUANES, Adauto. O costume como fonte do direito internacional: relembrando Nuremberg. In: FRANCO, Alberto Silva; NUCCI, Guilherme de Souza. Doutrinas essenciais - direito penal. São Paulo: Revista dos Tribunais, 2010, v. 1.

TAVARES, André Ramos. Curso de direito constitucional. 10. ed. São Paulo: Saraiva, 2012. 